\title{
COVID-19-Related Web Search Behaviors and Infodemic Attitudes in Italy: Infodemiological Study
}

\author{
Alessandro Rovetta ${ }^{1 *}, \mathrm{MS}$; Akshaya Srikanth Bhagavathula ${ }^{2^{*}}$, PharmD \\ ${ }^{1}$ Mensana srls, Research and Disclosure Division, Brescia, Italy \\ ${ }^{2}$ Institute of Public Health, College of Medicine and Health Sciences, United Arab Emirates University, Abu Dhabi, United Arab Emirates \\ *all authors contributed equally
}

\section{Corresponding Author:}

Akshaya Srikanth Bhagavathula, PharmD

Institute of Public Health, College of Medicine and Health Sciences

United Arab Emirates University

Al Ain

Abu Dhabi, 17666

United Arab Emirates

Phone: 97154322 ext 6187

Email: akshaypharmd@gmail.com

\section{Abstract}

Background: Since the beginning of the novel coronavirus disease (COVID-19) outbreak, fake news and misleading information have circulated worldwide, which can profoundly affect public health communication.

Objective: We investigated online search behavior related to the COVID-19 outbreak and the attitudes of "infodemic monikers" (ie, erroneous information that gives rise to interpretative mistakes, fake news, episodes of racism, etc) circulating in Italy.

Methods: By using Google Trends to explore the internet search activity related to COVID-19 from January to March 2020, article titles from the most read newspapers and government websites were mined to investigate the attitudes of infodemic monikers circulating across various regions and cities in Italy. Search volume values and average peak comparison (APC) values were used to analyze the results.

Results: Keywords such as "novel coronavirus," "China coronavirus," "COVID-19," "2019-nCOV," and "SARS-COV-2" were the top infodemic and scientific COVID-19 terms trending in Italy. The top five searches related to health were "face masks," "amuchina" (disinfectant), "symptoms of the novel coronavirus," "health bulletin," and "vaccines for coronavirus." The regions of Umbria and Basilicata recorded a high number of infodemic monikers (APC weighted total >140). Misinformation was widely circulated in the Campania region, and racism-related information was widespread in Umbria and Basilicata. These monikers were frequently searched (APC weighted total >100) in more than 10 major cities in Italy, including Rome.

Conclusions: We identified a growing regional and population-level interest in COVID-19 in Italy. The majority of searches were related to amuchina, face masks, health bulletins, and COVID-19 symptoms. Since a large number of infodemic monikers were observed across Italy, we recommend that health agencies use Google Trends to predict human behavior as well as to manage misinformation circulation in Italy.

(JMIR Public Health Surveill 2020;6(2):e19374) doi: 10.2196/19374

\section{KEYWORDS}

novel coronavirus, COVID-19, Google search; Google Trends; infodemiology, infodemic monikers, Italy; behavior; public health; communication; digital health; online search

\section{Introduction}

The internet is the largest and fastest source to obtain health information, and millions of people seek health information online every day [1]. In the context of the novel coronavirus disease (COVID-19) pandemic, people around the world are forced to stay at home and turn to the internet for work and to stay connected with others. As the COVID-19 outbreak continues, the need to obtain information about the disease, its prevention, and risk communication has become greater for people. 
"Infodemiological" methods, such as an online search of traffic on Google, are widely used to understand the searching behaviors of the public during an epidemic, as well as for public health surveillance purposes [2-7]. Several online sources, such as Facebook, Twitter, and electronic health records, have wide application in infodemiological studies [8-10]. Indeed, the Google Trends tool provides both real-time and achieved information on trends (eg, variations in online interest in selected keywords and topics over time) [11-13]. In particular, Google Trends enables the analysis and forecasting of sensitive health topics such as AIDS, illegal drug use, and metal health [13]. Therefore, trend data generated by Google search volume can offer valuable insights into population behavior and health-related phenomena, particularly during infectious disease outbreaks [7,14-17]. Since the beginning of the COVID-19 outbreak, fake news and misleading information have circulated all over the world, which profoundly affect public health communication and diminish preventive measures [18-21]. In this context, we investigated online search query behavior related to this pandemic and the extent of infodemic monikers circulating in Italy.

\section{Methods}

\section{Search Methodology}

We used Google Trends to explore internet search activity related to COVID-19 from January 21, 2020, to March 24, 2020. Article titles from the most read national newspapers and government websites were mined to investigate the extent and attitudes of various infodemic monikers related to COVID-19 that were circulating in Italy during the study period. We defined "infodemic monikers" as information that was substantially erroneous, which gave rise to interpretative mistakes, fake news, episodes of racism, or any other form of misleading information circulating on the internet.

Google Trends is an online tool that tracks keyword search queries users input in the Google search engine and determines their popularity and volume. It provides information on the search query according to a specific time period and location. The search volume results are scaled on a range of 0 (very low) to 100 (very high). Google Trends allows for the retrieval of queries for any keyword entered; up to five groups of terms can be compared at one time to explore the online interest in each term. By using this technique, we retrieved data from Google Trends using the keywords "Coronavirus" and "Coronavirus+" in the English and Italian languages. Each query with these keywords were also researched as the "search term" and "search topic." The "search term" provides the results for all keywords that fall within the category and the "search topic" provides the results of a group of terms that share the same concept in any language.

We used a previously described framework by Mavragani et al [22] for the region selection and time period selection to retrieve query data from Google Trends. First, we searched for the keyword COVID-19 and related terms at the country level to understand overall interest. Second, using this information, we retrieved interest by city and regions across Italy. Each keyword was searched independently between January 21, 2020, and
March 24, 2020. The data showing high values were further investigated manually to identify any event linked to the top searches. These queries were also cross-checked with news bulletins. By doing so, we identified the various infodemic monikers circulating across the country.

We reviewed the headlines of newspaper articles and government reports to identify their contribution in spreading infodemic monikers to the public. In order to obtain the search information from these media outlets, we used specific keywords frequently used in news and government report titles to quantify the average information values (AVs) of terms. The AVs were calculated as the number of monikers used in the headlines per 5 days. In order to characterize the obtained infodemic monikers, we categorized infodemic attitudes into 4 groups:

1. Superficial attitude:

the user adopts words that can generate confusion since they do not uniquely identify the topic (eg, coronavirus).

2. Misinformative attitude:

the user adopts words that can lead to the spread of fake news (eg, 5G coronavirus).

3. Racist attitude:

the user adopts words that, voluntarily or not, generate or accentuate episodes of racism (eg, Chinese coronavirus).

4. Definitive attitude:

the user adopts the most appropriate terms for the correct identification of the query (eg, COVID-19).

\section{Available Data and Materials, Ethical Approval, and Funding}

All materials were obtained from anonymous open-source data. Thus, ethical approval was not required. No external funding was provided for this study.

\section{Results}

\section{Overview}

The top five infodemic and scientific COVID-19 terms trending in Italy, according to inputs in Google search, were "novel coronavirus," "China coronavirus," "COVID-19," "2019-nCOV," and "SARS-COV-2" (Figure 1). From February 20 to March 24, 2020, the keyword that yielded the greatest search value was "coronavirus"; it had a search volume of 59 (SD 9). The other keywords' average peak comparison (APC) values were neglected compared to the latter (Multimedia Appendix 1). The keywords that showed APC $<1$ are omitted for further investigation. On March 22, 2020, excluding the term "coronavirus" from the cluster, the query related to "novel coronavirus" had the highest value (ie, 100). On the previous day, Italy recorded the highest number of new cases $(n=6577)$, and the government enforced lockdown measures. In contrast, "China coronavirus" was the most commonly used query since the beginning of the COVID-19 outbreak in January 2020. Furthermore, the terms "China coronavirus" (value 38, SD 4), "novel coronavirus" (value 21, SD 6), and "COVID-19" (value 17, SD 3 ) were the most frequently used queries since February 20, 2020, when Italy become an epicenter of the COVID-19 outbreak. 
With respect to public restlessness in Italy, "face masks," "amuchina" (disinfectant) (value 23, SD 6), "symptoms of the novel coronavirus," "health bulletin," and "vaccine for coronavirus" were the top five searches related to health. During the early period of the COVID-19 outbreak, there was a spike in queries regarding symptoms, followed by face masks and disinfectants (Figure 2). In particular, on February 22, 2020, disinfectant-related searches in Italy reached the breakout stage, with a search value of 100. Later, public restlessness appeared to drive an immense increase in queries related to the symptoms of COVID-19. Moreover, on March 11, 2020, there was a tremendous increase in the top five searches related to COVID-19.

We also referred to two widely read Italian newspapers-Il Sole 24 Ore and La Repubblica - that have been publishing a large number of articles related to COVID-19, as well as government websites, to investigate AVs. We found that most of the Italian public used the keyword "coronavirus" to obtain information in La Repubblica (AV 127, SD 50) and Il Sole 24 Ore (AV 113, SD 46), while government bulletins were not routinely used (AV 22, SD 9). Detailed information on the keywords used to identify information related to COVID-19 during the pandemic period is shown in Figure 3 and Multimedia Appendix 2.

Our findings indicate that the regions with the most amount of COVID-19 cases were not always the first to circulate key infodemic monikers. For instance, regions such as Umbria and Basilicata had the highest number of infodemic monikers (APC weighted total $>140$ ), while the number of cases reported in these regions was limited from January to March 2020 (Figure 4). Furthermore, the presence of these monikers was particularly pronounced (APC weighted total >100) across several cities in Italy, in particular, Pescara and Bologna (Figure 5).

Figure 1. The top infodemic and scientific terms relating to coronavirus disease (COVID-19) trending in Italy.

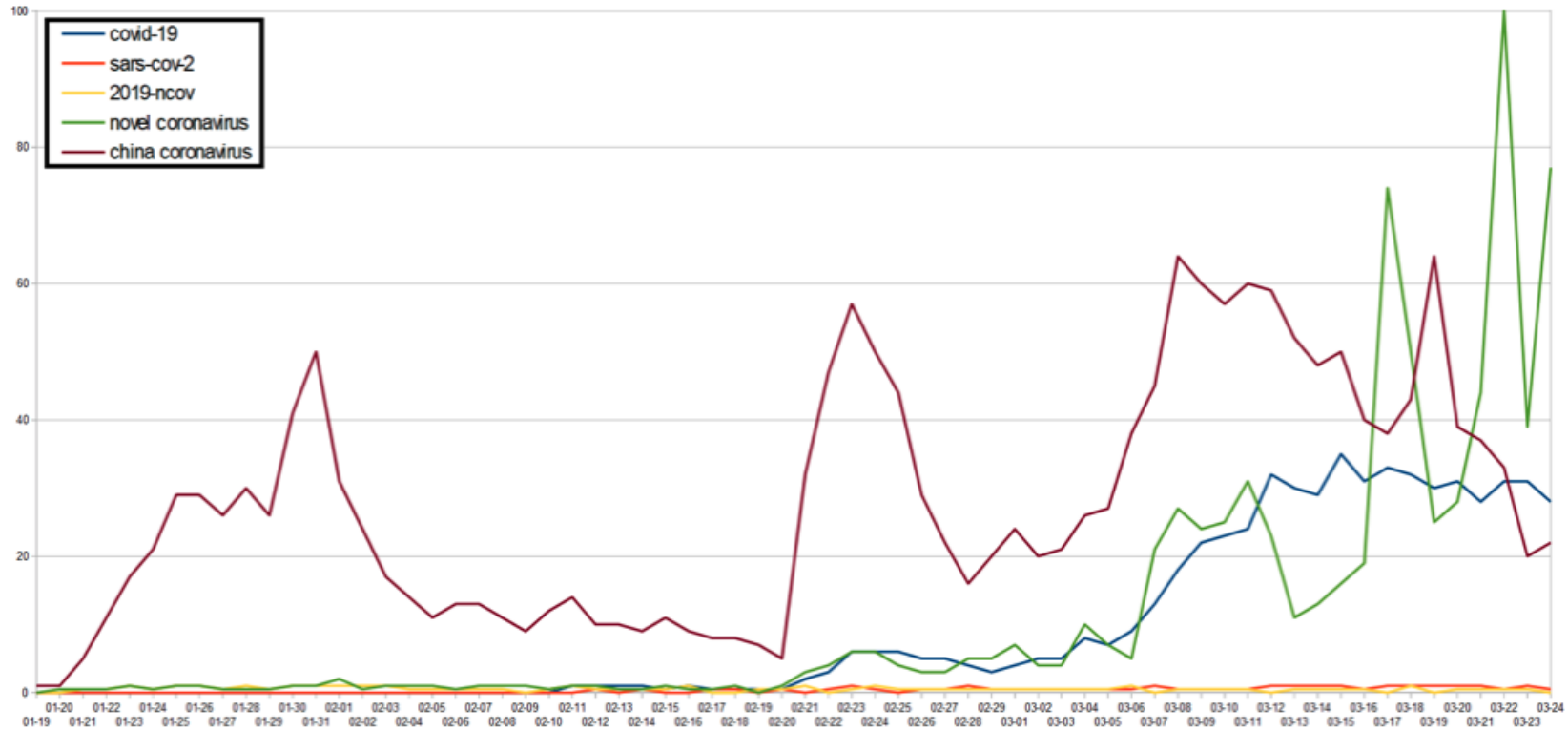

Figure 2. The top five searches related to health.

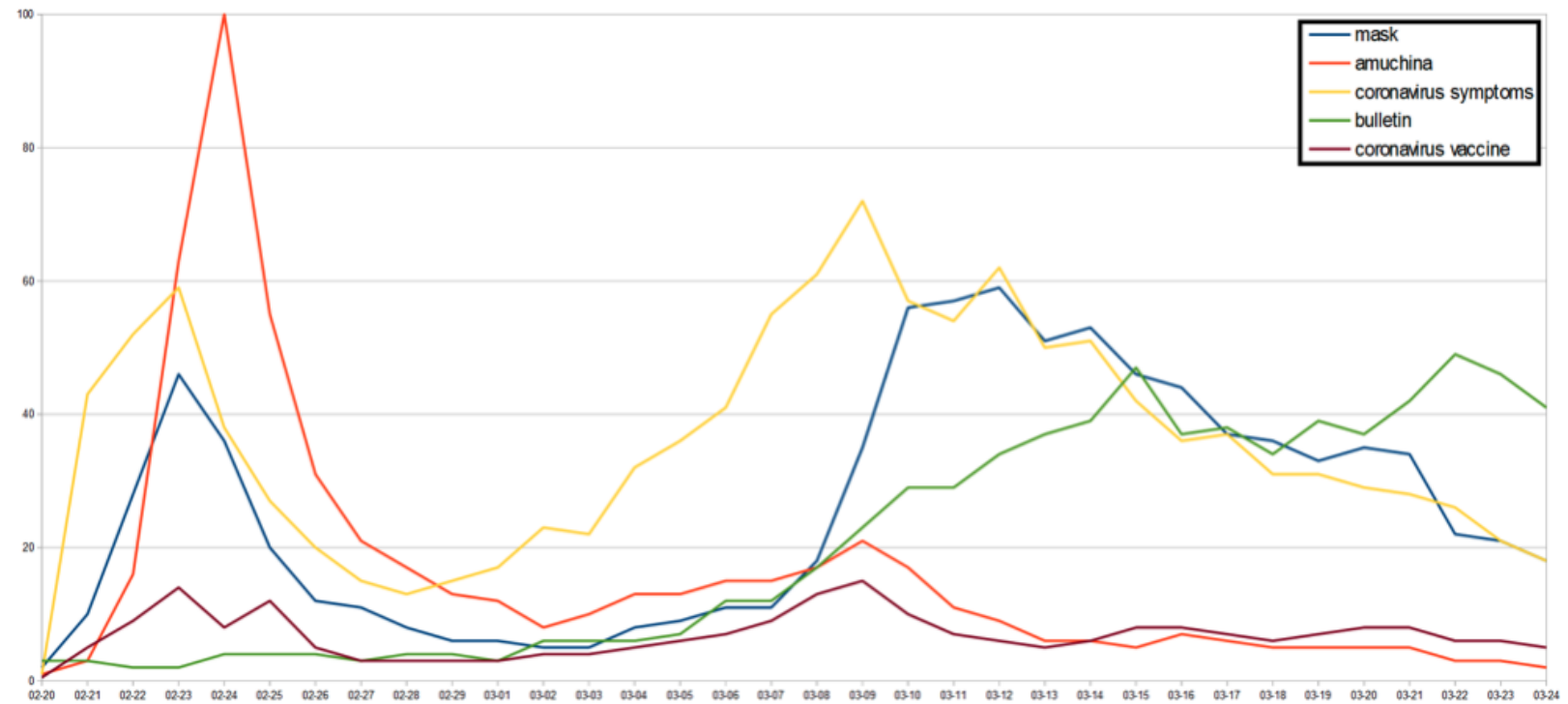


Figure 3. Keywords used to identify information related to coronavirus disease (COVID-19): Il Sole 24 Ore (I) and La Repubblica (II) newspapers, and government bulletins (III).

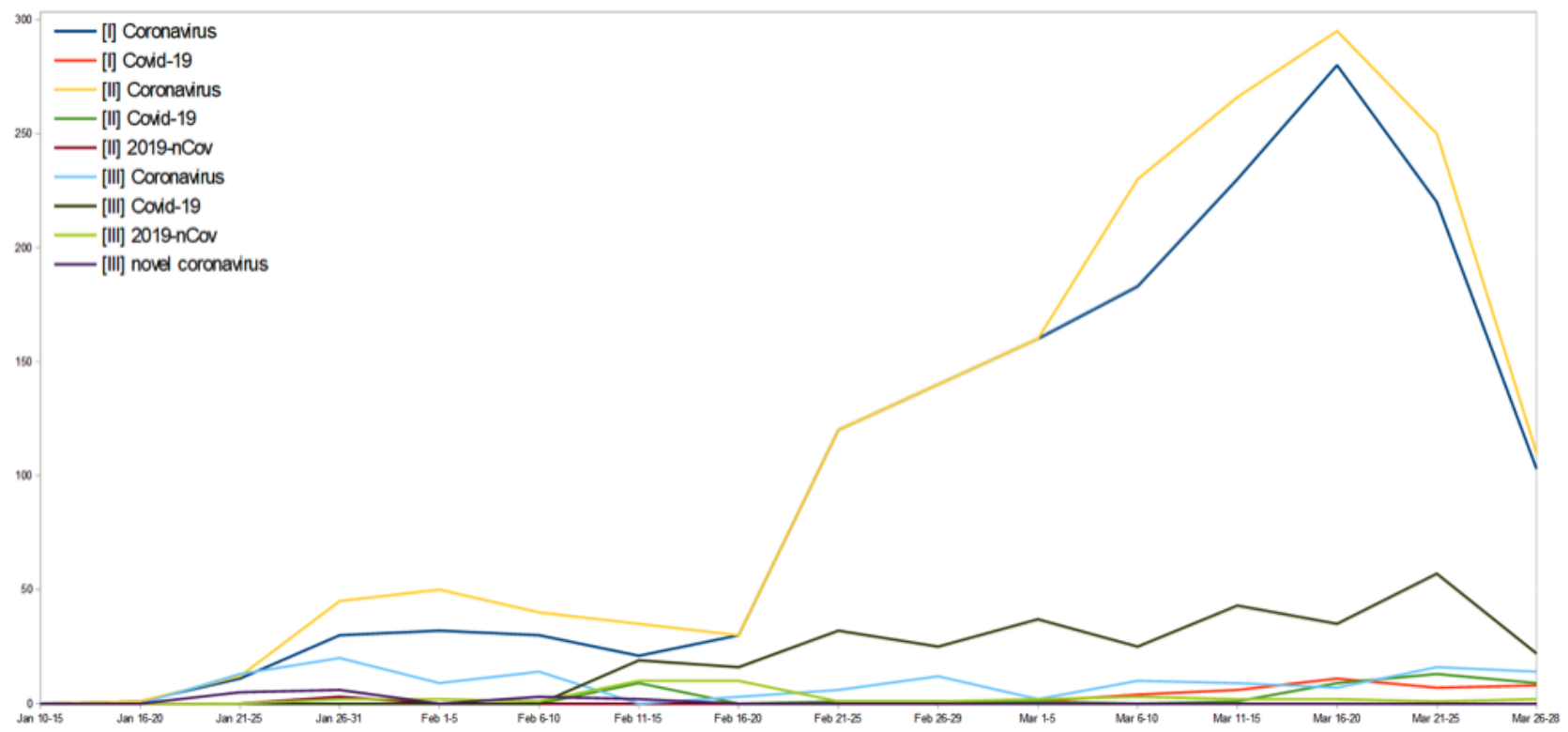

Figure 4. Regional dispersion of infodemic monikers about coronavirus disease (COVID-19) in Italy. APC: average peak comparison.

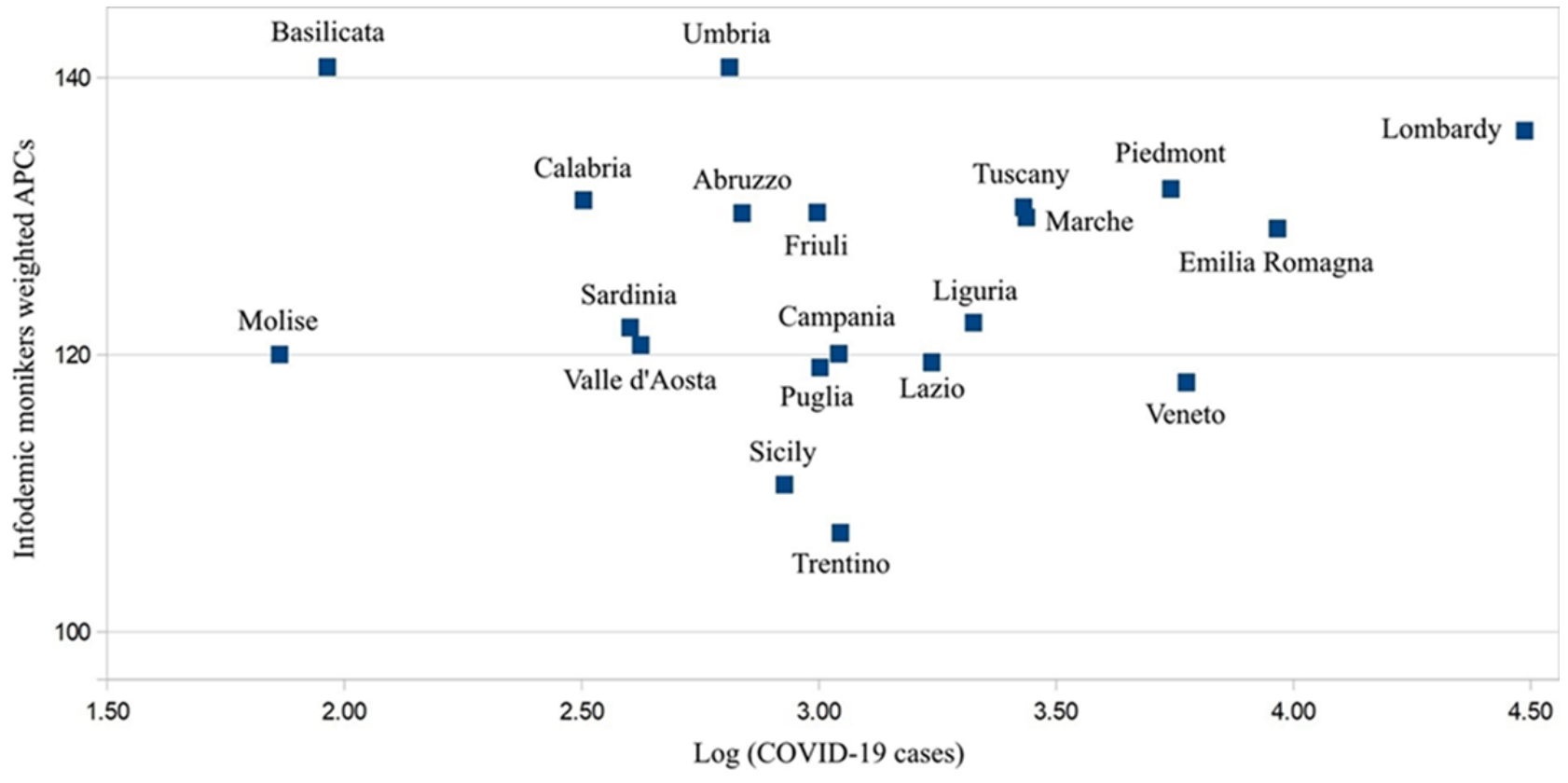


Figure 5. Dispersion of infodemic monikers about coronavirus disease (COVID-19) circulating across various cities in Italy. APC: average peak comparison.

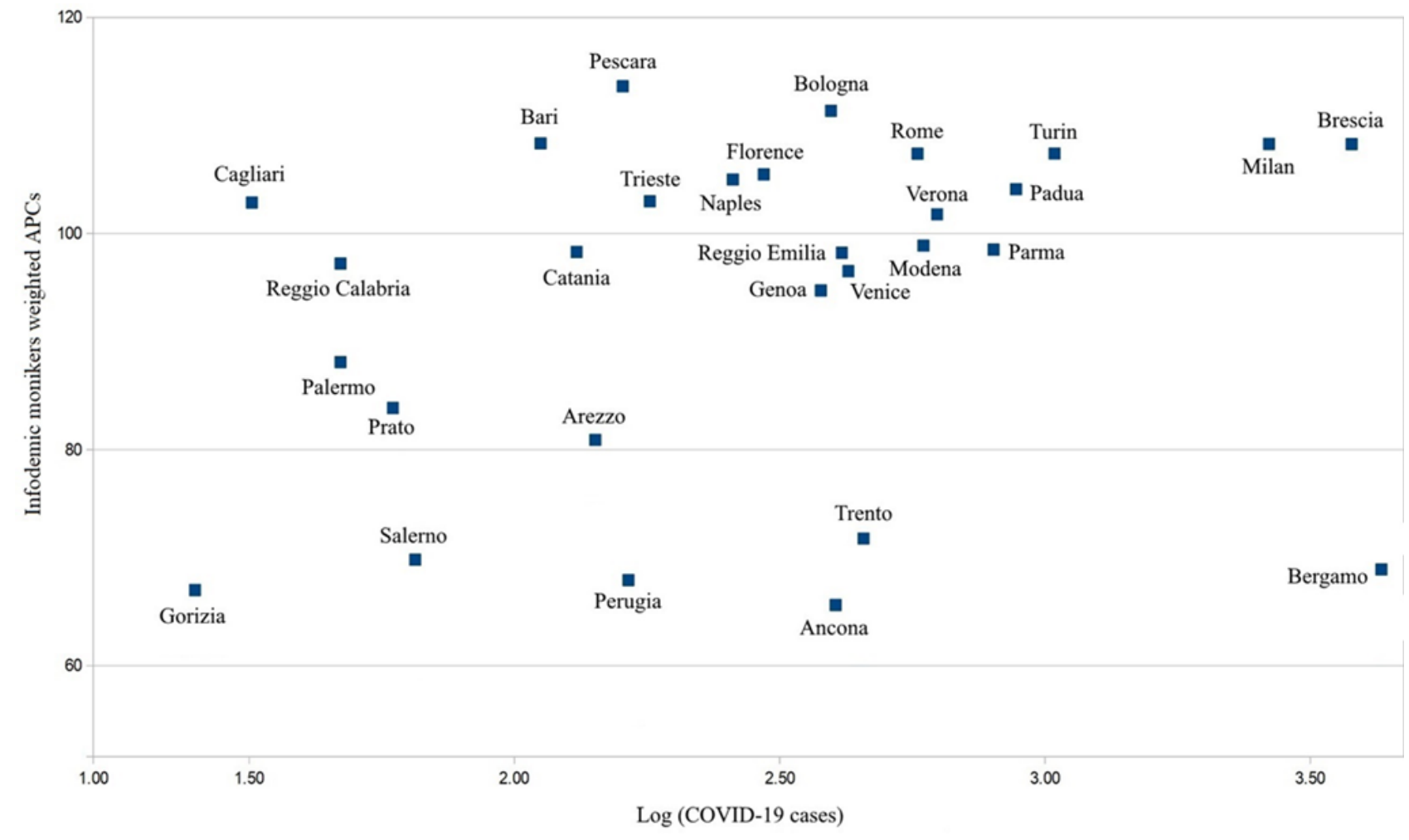

\section{Infodemic Attitudes}

The infodemic attitudes of various types of information that circulated across Italy during the study period are presented in Table 1. Most COVID-19-related information that circulated in the regions of Basilicata, Umbria, and Emilia Romagna were found to be superficial and did not provide clearer information on COVID-19. Misinformation was widespread in Umbria and Basilicata. As COVID-19 spread across the world from China, most information related to racism, such as "China coronavirus," "Chinese virus," "Chinese coronavirus," and "Wuhan virus," were more frequently searched in the Campania and Friuli Venezia Giulia regions. 
Table 1. Attitudes of infodemic monikers on coronavirus disease (COVID-19) in circulation across Italy between January 21, 2020, and March 24, 2020.

\begin{tabular}{|c|c|c|c|c|c|c|}
\hline \multirow[t]{2}{*}{ Region } & \multirow[t]{2}{*}{ COVID-19 cases $^{\mathrm{a}}, \mathrm{n}$} & \multirow[t]{2}{*}{ Total $\mathrm{APC}^{\mathrm{b}}$ value } & \multicolumn{4}{|c|}{ APC values of infodemic attitudes (1-100) } \\
\hline & & & Superficial & Misinformation & Racial & Definitive \\
\hline Lombardia & 30,703 & 275 & 95 & 68 & 83 & 71 \\
\hline Emilia Romagna & 9254 & 296 & 97 & 79 & 89 & 69 \\
\hline Veneto & 5948 & 256 & 84 & 61 & 82 & 71 \\
\hline Piemonte & 5515 & 286 & 96 & 76 & 89 & 75 \\
\hline Marche & 2736 & 279 & 93 & 78 & 88 & 80 \\
\hline Toscana & 2699 & 293 & 94 & 88 & 89 & 78 \\
\hline Liguria & 2116 & 270 & 88 & 74 & 90 & 82 \\
\hline Lazio & 1728 & 269 & 89 & 76 & 79 & 75 \\
\hline Campania & 1101 & 281 & 88 & 75 & 100 & 82 \\
\hline Trentino-Alto Adige & 1110 & 228 & 80 & 63 & 57 & 72 \\
\hline Puglia & 1005 & 268 & 87 & 78 & 87 & 84 \\
\hline Friuli Venezia Giulia & 992 & 267 & 94 & 75 & 98 & 100 \\
\hline Sicilia & 846 & 268 & 81 & 68 & 84 & 65 \\
\hline Abruzzo & 689 & 292 & 92 & 84 & 97 & 81 \\
\hline Umbria & 648 & 312 & 97 & 100 & 92 & 77 \\
\hline Valle d'Aosta & 400 & 239 & 89 & 70 & 36 & 56 \\
\hline Sardegna & 421 & 255 & 89 & 64 & 95 & 93 \\
\hline Calabria & 319 & 281 & 91 & 86 & 87 & 83 \\
\hline Basilicata & 92 & 306 & 100 & 92 & 96 & 82 \\
\hline Molise & 73 & 237 & 87 & 84 & 66 & 92 \\
\hline
\end{tabular}

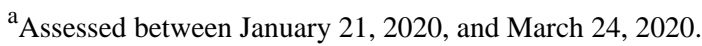

${ }^{\mathrm{b}}$ APC: average peak comparison.

\section{Discussion}

\section{Principal Findings}

This is the first study to investigate the online search behaviors of the public in the context of the COVID-19 pandemic. We aimed to uncover the extent and the attitudes of infodemic monikers that circulated in Italy during the study period. Previously published studies have investigated Google Trends and Twitter activities related to COVID-19 but were conducted in China [23,24], Taiwan [25], the United States [26], and Spain [27]. In summary, we identified "novel coronavirus," "China coronavirus," "COVID-19," “2019-nCOV," and "SARS-COV-2" as the top infodemic and scientific COVID-19 terms trending in Italy. "Face masks," "amuchina," "symptoms of the novel coronavirus," "health bulletins," and "vaccines for coronavirus" were the top five searches related to health. Several infodemic monikers have widespread circulation in major Italian cities. In particularly, misinformation was widely circulated in the Campania region and racism-related information in Umbria and Basilicata.

The current COVID-19 pandemic has threatened global public health and has generated millions of internet searches worldwide. In Italy, "China coronavirus" was the most frequently searched term on Google, coinciding with the first incidence of COVID-19 in 2 Chinese tourists, as announced by the Italian Prime Minister Giuseppe Conte at the end of January 2020 [28]. However, the increasing number of cases did not generate a significant number of web searches until the World Health Organization (WHO) declared the COVID-19 outbreak as a pandemic [29], and the Italian government imposed draconian rules to stop the spread in early March 2020 [30]. Notably, queries related to COVID-19 symptoms, disinfectants, masks, and vaccines were relatively high in the fourth week of February 2020, stabilized in 20 values during early March, and quickly increased as the number of cases increased in Italy. This is indicative of peoples' restlessness with regard to gathering information about necessary personal protection and hygiene practices as COVID-19 cases rose in Italy. Of note, around 40,000 people were charged for violating the lockdown, and the often-mentioned reasons to go out were "amuchina, " "face masks," and other casual reasons [31]. These reasons are also reflected in our research and, thus, diminish countermeasures for the outbreak in Italy. To curtail this, the government has initiated a "self-certification" form to declare a valid reason such as work, health reasons, or buying food that necessitates leaving the house. 
The findings of our study suggest that web search interest in COVID-19, both at the regional level and in cities in Italy, were influenced by tradition, electronic newspapers, and print media coverage. For instance, people preferred to use the term "Coronavirus" more frequently to obtain information in newspapers instead of "COVID-19," "2019-nCOV," and "novel coronavirus." Data from previous research suggest delivering information through Twitter and electronic news outlets frequently focus more on spreading news disproportionately than awareness and educational campaigns [32-34]. These observations have important implications in generating COVID-19-related restlessness in the general public in Italy. Further research is warranted.

Through our investigation, we identified several infodemic monikers of COVID-19 that impinged public communication across various cities in Italy. Misinformation during an outbreak can profoundly affect public health communication and create xenophobia between nations [35-39]. Disseminating fake news and racism across social media has become a widespread practice, and the COVID-19 outbreak is no exception $[39,40]$. Misinformation and anti-Asian sentiments have increased around the world [39,41,42]. In Italy, several incidences of discrimination and anti-Chinese sentiments were reported [43-45]; however, we believe that the rate of information related to racism that circulated across the country could be the true confounding factor contributing to xenophobia.

The failures of Chinese authorities to handle the virus at an early stage has resulted in the spread of COVID-19 across the world, with new cases arising from ongoing human-to-human transmission as well as from asymptomatic individuals [46].
Additionally, preliminary investigations by the WHO denied the possibility of human-to-human transmission of COVID-19 [47]. We assume that this type of misleading information may have resulted in the instigation of angry online conversations among netizens in Italy. Although we did not delve deeper into the type of potential misinformation that spread across Italy, we believe that dispersing misinformation can create agitation, cause fear, and ultimately diminish preventive measures for the outbreak. Journalists and mass media regulators have an important role in delivering comprehensive information to citizens, as well as taking serious actions on those spreading misinformation.

\section{Limitations}

Our study had some limitations to consider. Google Trends captures the search behavior of people who use the Google search engine. Consequently, people using other search engines were not investigated. Also, we relied on the accuracy of data provided by Google Trends and do not have any information about the methods used by Google to generate search data and algorithms.

\section{Conclusion}

Using Google Trends, the present study identified that Google search query data reflect a growing regional and population-level interest in COVID-19. Searches related to disinfectants, face masks, health bulletins, and vaccines and symptoms related to COVID-19 were top search keywords. However, a large number (APC weighted total >140) of infodemic monikers have been circulating in Italy. Therefore, health agencies can use Google Trends to predict human behavior as well as tackle the misinformation that is currently circulating in Italy.

\section{Conflicts of Interest}

None declared.

\section{Multimedia Appendix 1}

The most searched infodemic words for group type.

[DOCX File, 260 KB-Multimedia Appendix 1]

\section{Multimedia Appendix 2}

Keywords used to search the infodemic monikers.

[DOCX File, 13 KB-Multimedia Appendix 2]

\section{References}

1. International Telecommunications Union/UNESCO. 2017 Aug 01. The state of broadband 2017: broadband catalyzing sustainable development URL: https://www.itu.int/dms pub/itu-s/opb/pol/S-POL-BROADBAND.18-2017-PDF-E.pdf [accessed 2020-04-07]

2. Mollema L, Harmsen IA, Broekhuizen E, Clijnk R, De Melker H, Paulussen T, et al. Disease detection or public opinion reflection? Content analysis of tweets, other social media, and online newspapers during the measles outbreak in The Netherlands in 2013. J Med Internet Res 2015 May 26;17(5):e128 [FREE Full text] [doi: 10.2196/jmir.3863] [Medline: 26013683]

3. Chen Y, Zhang Y, Xu Z, Wang X, Lu J, Hu W. Avian Influenza A (H7N9) and related Internet search query data in China. Sci Rep 2019 Jul 18;9(1):10434 [FREE Full text] [doi: 10.1038/s41598-019-46898-y] [Medline: $\underline{31320681]}$

4. Mohamed NA. Knowledge, Attitude and Practice on Bats-Borne Diseases among Village Residents: A Pilot Study. MH 2018 Dec 31;13(2):48-57 [FREE Full text] [doi: 10.17576/MH.2018.1302.05] 
5. Zeraatkar K, Ahmadi M. Trends of infodemiology studies: a scoping review. Health Info Libr J 2018 Jun 04;35(2):91-120. [doi: 10.1111/hir.12216] [Medline: 29729073]

6. Tang L, Bie B, Park S, Zhi D. Social media and outbreaks of emerging infectious diseases: A systematic review of literature. Am J Infect Control 2018 Sep;46(9):962-972 [FREE Full text] [doi: 10.1016/j.ajic.2018.02.010] [Medline: 29628293]

7. Eysenbach G. SARS and population health technology. J Med Internet Res 2003 Jun 30;5(2):e14 [FREE Full text] [doi: 10.2196/jmir.5.2.e14] [Medline: 12857670]

8. Mavragani A, Ochoa G. Infoveillance of infectious diseases in USA: STDs, tuberculosis, and hepatitis. J Big Data 2018 Sep 6;5(1). [doi: 10.1186/s40537-018-0140-9]

9. Roccetti M, Marfia G, Salomoni P, Prandi C, Zagari RM, Gningaye Kengni FL, et al. Attitudes of Crohn's Disease Patients: Infodemiology Case Study and Sentiment Analysis of Facebook and Twitter Posts. JMIR Public Health Surveill 2017 Aug 09;3(3):e51 [FREE Full text] [doi: 10.2196/publichealth.7004] [Medline: 28793981]

10. Bragazzi NL, Alicino C, Trucchi C, Paganino C, Barberis I, Martini M, et al. Global reaction to the recent outbreaks of Zika virus: Insights from a Big Data analysis. PLoS One 2017 Sep 21;12(9):e0185263 [FREE Full text] [doi: 10.1371/journal.pone.0185263] [Medline: 28934352]

11. Google Inc. 2020. Google Trends URL: https://trends.google.com [accessed 2020-04-01]

12. Eysenbach G. Infodemiology and infoveillance: framework for an emerging set of public health informatics methods to analyze search, communication and publication behavior on the Internet. J Med Internet Res 2009 Mar 27;11(1):e11 [FREE Full text] [doi: 10.2196/jmir.1157] [Medline: 19329408]

13. Mavragani A, Ochoa G. Google Trends in Infodemiology and Infoveillance: Methodology Framework. JMIR Public Health Surveill 2019 May 29;5(2):e13439 [FREE Full text] [doi: 10.2196/13439] [Medline: $\underline{\text { 31144671] }}$

14. Fung IC, Fu K, Ying Y, Schaible B, Hao Y, Chan C, et al. Chinese social media reaction to the MERS-CoV and avian influenza A (H7N9) outbreaks. Infect Dis Poverty 2013 Dec 20;2(1):31 [FREE Full text] [doi: 10.1186/2049-9957-2-31] [Medline: 24359669]

15. Hossain L, Kam D, Kong F, Wigand RT, Bossomaier T. Social media in Ebola outbreak. Epidemiol Infect 2016 Mar 04;144(10):2136-2143. [doi: 10.1017/s095026881600039x]

16. Carneiro H, Mylonakis E. Google Trends: a web-based tool for real-time surveillance of disease outbreaks. Clin Infect Dis 2009 Nov 15;49(10):1557-1564. [doi: 10.1086/630200] [Medline: 19845471 ]

17. Li C, Chen L, Chen X, Zhang M, Pang C, Chen H. Retrospective analysis of the possibility of predicting the COVID-19 outbreak from Internet searches and social media data, China, 2020. Euro Surveill 2020 Mar;25(10):2000199 [FREE Full text] [doi: 10.2807/1560-7917.ES.2020.25.10.2000199] [Medline: 32183935]

18. Pulido CM, Villarejo-Carballido B, Redondo-Sama G, Gómez A. COVID-19 infodemic: More retweets for science-based information on coronavirus than for false information. International Sociology 2020 Apr 15:026858092091475. [doi: $10.1177 / 0268580920914755]$

19. Pulido Rodríguez C, Villarejo Carballido B, Redondo-Sama G, Guo M, Ramis M, Flecha R. False news around COVID-19 circulated less on Sina Weibo than on Twitter. How to overcome false information? RIMCIS 2020 Apr 13:1. [doi: 10.17583/rimcis.2020.5386]

20. Abd-Alrazaq A, Alhuwail D, Househ M, Hamdi M, Shah Z. Top Concerns of Tweeters During the COVID-19 Pandemic: Infoveillance Study. J Med Internet Res 2020 Apr 21;22(4):e19016 [FREE Full text] [doi: 10.2196/19016] [Medline: $\underline{32287039]}$

21. Liew S, Khoo E, Cheah W, Goh P, Ibrahim H. We have to write and share valid and reliable information on COVID-19. Malays Fam Physician 2020;15(1):1 [FREE Full text] [Medline: 32284797]

22. Mavragani A, Ochoa G. Google Trends in Infodemiology and Infoveillance: Methodology Framework. JMIR Public Health Surveill 2019 May 29;5(2):e13439 [FREE Full text] [doi: 10.2196/13439] [Medline: 31144671]

23. Strzelecki A, Rizun M. Infodemiological Study Using Google Trends on Coronavirus Epidemic in Wuhan, China. Int. J. Onl. Eng 2020 Apr 08;16(04):139. [doi: 10.3991/ijoe.v16i04.13531]

24. Hu Z, Yang Z, Li Q, Zhang A, Huang Y. Infodemiological study on COVID-19 epidemic and COVID-19 infodemic. Preprints.org 2020 Mar 16 [FREE Full text] [doi: 10.20944/preprints202002.0380.v3]

25. Husnayain A, Fuad A, Su EC. Applications of google search trends for risk communication in infectious disease management: A case study of COVID-19 outbreak in Taiwan. Int J Infect Dis 2020 Mar 12 [FREE Full text] [doi: 10.1016/j.ijid.2020.03.021] [Medline: 32173572]

26. Chen E, Lerman K, Ferrara E. COVID-19: The First Public Coronavirus Twitter Dataset. arxiv.org 2020 Mar 16 [FREE Full text]

27. Hernández-García I, Giménez-Júlvez T. Assessment of Health Information About COVID-19 Prevention on the Internet: Infodemiological Study. JMIR Public Health Surveill 2020 Apr 01;6(2):e18717 [FREE Full text] [doi: 10.2196/18717] [Medline: 32217507]

28. Reuters. 2020 Jan 31. Two first coronavirus cases confirmed in Italy: Prime Minister URL: https://www.reuters.com/article/ us-china-health-italy/two-first-coronavirus-cases-confirmed-in-italy-prime-minister.html [accessed 2020-04-09] 
29. World Health Organization. 2020 Mar 11. WHO Director-General's opening remarks at the media briefing on COVID-19 - 11 March 2020 URL: https://www.who.int/dg/speeches/detail/ who-director-general-s-opening-remarks-at-the-media-briefing-on-covid-19---11-march-2020 [accessed 2020-04-09]

30. NY Times. 2020 Mar 08. On Day 1 of Lockdown, Italian Officials Urge Citizens to Abide by Rules URL: https://www. nytimes.com/2020/03/08/world/europe/italy-coronavirus-quarantine.html [accessed 2020-04-09]

31. The Guardian. 2020 Mar 18. Italy charges more than 40,000 people with violating lockdown URL: https://www. theguardian.com/world/2020/mar/18/italy-charges-more-than-40000-people-violating-lockdown-coronavirus [accessed 2020-03-30]

32. Househ M. Communicating Ebola through social media and electronic news media outlets: A cross-sectional study. Health Informatics J 2016 Sep 26;22(3):470-478. [doi: 10.1177/1460458214568037] [Medline: 25656678]

33. Kwak H, An J, Salminen J, Jung S, Jansen B. What we read, what we search: Media attention and public attention among 193 countries. 2018 Apr 18 Presented at: Proceedings of the 2018 World Wide Web Conference; 2018 April 23; Geneva p. 893-902. [doi: $10.1145 / 3178876.3186137]$

34. Southwell BG, Dolina S, Jimenez-Magdaleno K, Squiers LB, Kelly BJ. Zika Virus-Related News Coverage and Online Behavior, United States, Guatemala, and Brazil. Emerg Infect Dis 2016 Jul;22(7):1320-1321 [FREE Full text] [doi: 10.3201/eid2207.160415] [Medline: 27100826]

35. Chandler C, Fairhead J, Kelly A, Leach M, Martineau F, Mokuwa E, et al. Ebola: limitations of correcting misinformation. The Lancet 2015 Apr;385(9975):1275-1277. [doi: 10.1016/s0140-6736(14)62382-5]

36. Ortiz-Martínez Y, Jiménez-Arcia LF. Yellow fever outbreaks and Twitter: Rumors and misinformation. Am J Infect Control 2017 Jul 01;45(7):816-817. [doi: 10.1016/j.ajic.2017.02.027] [Medline: 28343702]

37. Gesser-Edelsburg A, Diamant A, Hijazi R, Mesch GS. Correcting misinformation by health organizations during measles outbreaks: A controlled experiment. PLoS One 2018 Dec 19;13(12):e0209505 [FREE Full text] [doi:

10.1371/journal.pone.0209505] [Medline: $\underline{\text { 30566485] }}$

38. Vijaykumar S, Nowak G, Himelboim I, Jin Y. Managing social media rumors and misinformation during outbreaks. Am J Infect Control 2018 Jul;46(7):850. [doi: 10.1016/j.ajic.2018.03.014] [Medline: 29661633]

39. Shimizu K. 2019-nCoV, fake news, and racism. The Lancet $2020 \mathrm{Feb} ; 395(10225): 685-686$. [doi: 10.1016/s0140-6736(20)30357-3]

40. Mejova Y, Kalimeri K. Advertisers jump on coronavirus bandwagon: Politics, news, and business. arxiv.org 2020 Mar 02 [FREE Full text]

41. NY Times. 2020 Jan 30. As coronavirus spreads, so does anti-chinese setiment URL: https://www.nytimes.com/2020/01/ 30/world/asia/coronavirus-chinese-racism.html [accessed 2020-03-03]

42. Time. 2020 Feb 29. As Coronavirus Spreads, So Does Xenophobia and Anti-Asian Racism URL: https:/time.com/5797836/ coronavirus-racism-stereotypes-attacks/ [accessed 2020-04-09]

43. Chung RY, Li MM. Anti-Chinese sentiment during the 2019-nCoV outbreak. The Lancet 2020 Feb;395(10225):686-687. [doi: 10.1016/s0140-6736(20)30358-5]

44. Open. 2020 Feb 26. L'incubo di essere cinesi in Italia con il coronavirus: «Un ragazzo preso a bottigliate in Veneto» URL: https://www.open.online/2020/02/26/

lincubo-di-essere-cinesi-in-italia-con-il-coronavirus-un-ragazzo-preso-a-bottigliate-in-veneto/ [accessed 2020-03-30]

45. South China Morning Post. 2020 Mar 30. I am not a virus, I am a human being: Italian-Chinese man?s video spreads anti-racist message on social media URL: https:/www.scmp.com/news/china/society/article/3050499/ i-am-not-virus-i-am-human-being-italian-chinese-mans-video [accessed 2020-03-30]

46. Rodríguez-Morales AJ, MacGregor K, Kanagarajah S, Patel D, Schlagenhauf P. Going global - Travel and the 2019 novel coronavirus. Travel Med Infect Dis 2020 Jan;33:101578 [FREE Full text] [doi: 10.1016/j.tmaid.2020.101578] [Medline: $\underline{32044389]}$

47. World Health Organization. Twitter. 2019 Jan 14. Preliminary Investigations Conducted by the Chinese Authorities Have Found No Clear Evidence of Human-to-Human Transmission of the Novel \#Coronavirus URL: https://twitter.com/who/ status/1217043229427761152?lang=en [accessed 2020-04-21]

\section{Abbreviations}

APC: average peak comparison

AV: average information value

COVID-19: coronavirus disease

WHO: World Health Organization 
Edited by G Eysenbach; submitted 15.04.20; peer-reviewed by E Alemayehu, A Mavragani; comments to author 17.04.20; revised version received 22.04.20; accepted 22.04.20; published 05.05.20

Please cite as:

Rovetta A, Bhagavathula AS

COVID-19-Related Web Search Behaviors and Infodemic Attitudes in Italy: Infodemiological Study

JMIR Public Health Surveill 2020;6(2):e19374

URL: http://publichealth.jmir.org/2020/2/e19374/

doi: 10.2196/19374

PMID: 32338613

(C)Alessandro Rovetta, Akshaya Srikanth Bhagavathula. Originally published in JMIR Public Health and Surveillance (http://publichealth.jmir.org), 05.05.2020. This is an open-access article distributed under the terms of the Creative Commons Attribution License (https://creativecommons.org/licenses/by/4.0/), which permits unrestricted use, distribution, and reproduction in any medium, provided the original work, first published in JMIR Public Health and Surveillance, is properly cited. The complete bibliographic information, a link to the original publication on http://publichealth.jmir.org, as well as this copyright and license information must be included. 